\title{
Frida Hastrup
}

Frida Hastrup, ph.d., er adjunkt i etnologi ved Saxo-Instituttet, Københavns Universitet. Hendes forskning fokuserer på opfattelser og praktiseringer af naturressourcer, bæredygtighed og handel med råvarer. Frida Hastrup er forskningsleder for det kollektive Sapere Aude-projekt Natural Goods? Processing Raw Materials in Global Times, hvis samlede mål er at producere detaljerede etnografiske analyser af, hvordan naturressourcer rummer og skaber interessante og potentielt problematiske ideer om globale forbindelser, kvantificeringer af naturen og værdisætninger af dens produkter.

Nøgleord: Naturressourcer, globale forbindelser, detaljer, værdi, etnografi, økonomisk botanik.

\section{MOD NYE FRUGTMARKEDER Forarbejdning af naturressourcer i kulturanalyse}

\author{
„...These results were not achieved without \\ some attention to detail" \\ Albert \& Gabrielle Howard i Bulletin of The Quetta Fruit Experiment Station, 1913.
}

Gennem en dialog med botanikere udsendt fra England til Britisk Indien for at udvikle handel med frugt i begyndelsen af det 20. århundrede udforsker denne artikel, hvad naturressourcer kan være i et kulturanalytisk perspektiv. Artiklen introducerer ideerne i forskningsprojektet Natural Goods? og tilbyder et radikalt etnografisk greb om naturressourcer, hvor disse anses for genereret og løbende kvalificeret i felten gennem en serie af møder mellem forskellige parter - mennesker, frugter eller andet. Den bærende idé i artiklen såvel som i forskningsprojektet som helhed er, at naturressourcer bliver til det, de er, gennem en detaljemættet og omhyggelig kollektiv forarbejdningsproces, som er praktisk og analytisk i en og samme bevægelse, hvilket har stor betydning for, hvad etnografi og feltarbejde kan være. 


\section{Introduktion: At skabe overskud af detaljer}

Udsendt i det engelske imperiums tjeneste i begyndelsen af det 20. århundrede kom botaniker-ægteparret Albert og Gabrielle Howard til at stå i spidsen først for The Imperial Agricultural Research Institute i Pusa, Bihar, i det nordøstlige Indien, og lidt senere for den såkaldte Quetta Fruit Experiment Station i provinsen Baluchistan i det nuværende Pakistan. I hovedbyen Quetta, hvor denne frugteksperiment-station lå, og som dengang var en del af Britisk Indien, fik i første omgang Albert og siden Gabrielle Howard titel af Imperial Economic Botanist. Under denne fane arbejdede de to for at udvikle og forbedre landbrugsproduktionen i Indien, og deres opdrag at gøre botanik økonomisk rentabel i imperiet indebar en masse vidtforgrenede aktiviteter (Gieryn 1999, s. 233 ff.). Således var Howards interesserede i at udforske og lære af lokale indiske dyrkningspraksisser, de konsulterede møllere og bagere hjemme i England for råd om forskellige hvedetypers relative kvaliteter, de eksperimenterede med måder at pakke ferskner til forsendelse på, ligesom de engagerede sig i de indiske jernbanefirmaers regler for fragt af frugt og grønt, for blot at nævne nogle af deres handlinger i den økonomiske botaniks tjeneste. I lyset af denne sammensatte og holistiske tilgang til afgrøder og deres videre færd kan det måske ikke undre, at Albert Howard ofte bliver fremhævet som en pioner for moderne biodynamisk landbrug (ibid.).

Et var botanikken og de observationer og erfaringer, Howards gjorde sig med rotation af afgrøder, forædling af sorter, kompostering og andre måder at sikre næringsstoffer til jorden uden brug af kemisk gødning. Alt det arbejde, der siden og herudover skulle til for at få lokalt dyrkede frugter og andre produkter til at rejse, sælge og være til glæde lå tilsyneladende også ægteparret Howard meget på sinde. At vise måder, hvorpå dyrkerne kunne skabe et overskud af deres overskydende produkter blev en hjørnesten i botanikernes virke (ibid., s. 250). I en serie af bulletiner udsendt fra The Quetta Fruit Experiment Station i årene 1913 til 1919, som jeg har arbejdet med på British Library i London, og som har inspireret mig til denne artikel, rapporterede Howards således omhyggeligt om forskellige initiativer, som deres frugteksperiment-station tog i forhold til forpakning og transport af frugter og grøntsager fra Quetta-området i den nordvestlige ende af det britisk-indiske territorium. Af disse skrifter fremgår det tydeligt, at der for Howards var et stort uudnyttet potentiale, som frugtavlere kunne realisere for at udstrække deres landbrugsproduktion med henblik på at skabe en bedre forretning af deres høst. En ny frugtindustri var moden til udvikling og nye markeder. Men dette krævede dog en omgående indsats, der via sans for allehånde forskellige detaljer af betydning for frugtens kvalitet og rejseevne kunne forbedre produktet og dermed afsætningen. I rapporterne lader det til både at undre og genere de økonomiske botanikere, at noget af den i øvrigt fantastiske frugt gik tabt 
efter plukning og i transit - i deres øjne på grund af unødigt sløset omgang med varerne. Gabrielle og Albert Howard så muligheder og tænkte anvendt:

„In several tracts in India, particularly on the Western Frontiers, excellent fruit can be produced, while in large cities, like Calcutta, Bombay and Delhi, markets exist for the produce (...) Experience in the plains at Pusa in Bihar and at Quetta on the Western Frontier, not only in the cultivation but also in the packing and transport of fruit, has shown quite clearly that an enormous amount of progress is possible.“ (A. \& G. Howard 1913).

For de økonomiske botanikere i Baluchistan var det urbane kraftcenter Calcutta fire dages togrejse mod sydøst, sammen med andre storbyer som Delhi og Bombay, altså attraktive mål, hvor producenter af frugt fra Quetta-området kunne afsætte deres varer til både indiske og europæiske aftagere - hvis man vel at mærke kunne få pakket og fragtet produkterne uskadte og i de rette mængder til storbyerne. I så fald lå afsætning lige for, og en ny type handel over langt længere afstande end hidtil muligt kunne begynde. Lad mig se nærmere på en passage fra 1913-bulletinen, som har titlen „,The Cultivation and Transport of Tomatoes in India“. En ganske lang bemærkning om den påkrævede omhu med tomaters indpakning er nødvendig:

„The plants should be separately wrapped in thin paper and only perfect specimens should be selected. There is obviously nothing to be gained in the attempt to send second-class produce, by passenger train, to a distant market like Calcutta, accustomed to handle the best supplies obtainable. Picking should be done early in the morning when the fruit is cold, and the packing should be done in the shade. By wrapping tomatoes in paper when cold, a great transport advantage is obtained. The ripening processes are delayed as cold-wrapped fruit heats up very slowly on the journey. In this respect, Baluchistan has an enormous natural advantage over its competitors in the fruit trade. With a little care, quite cold fruit can be packed at Quetta and all the advantages of pre-cooling before transport can be obtained without any trouble or expense. This enables fruit to be picked in a much riper condition than would otherwise be possible, thus ensuring the maximum flavour on arrival consistent with safe transport.“(A. \& G. Howard 1913).

For de to økonomiske botanikere blev tyndt papir, kølig morgenluft, skyggefulde steder og rigtigt timet plukning således anset for essentielle og konkurrencefordelagtige ingredienser i produktionen af tomater, hvis disse skulle kunne slå igennem som førsteklasses smag- og værdifulde handelsvarer blandt de forvænte aftagere i Calcutta. 
Denne tilgang til naturens ressourcer, altså at de udover eventuelt i udgangspunktet at være perfekte eksemplarer i botanisk forstand også bliver produceret og får værdi af deres forarbejdning, som den praktiseres gennem en opmærksomhed mod et samspil af detaljer, er baggrunden for, at disse hundrede år gamle hæfter fra Baluchistan i det daværende Britisk Indien interesserer mig her. I disse rapporter synes botanikerne nemlig direkte at adressere nogle af de spørgsmål, som også det kollektive forskningsprojekt Natural Goods? Processing Raw Materials in Global Times ved Saxo-Instituttet, Københavns Universitet nu udforsker. I denne artikel vil jeg således tale med Gabrielle og Albert Howard og bruge denne dialog til at udforske ambitionen i forskningsprojektet og dermed afprøve den form for fundamentalt etnografisk arbejde i felten, som det er drevet af, hvorigennem naturressourcer kommer til syne som genstand for interesse. Artiklens overordnede formål er således at bringe ideerne i vores kollektive forskningsprojekt i spil sammen med de imperiale botanikeres virke for at vise en tilgang til naturressourcer, hvor disse løbende bliver til via en detaljeret og ikke mindst fælles forarbejdningsproces, der får skellene mellem empiri og teori, data og analyse, kulturanalytiker og informant til at bryde fuldstændigt sammen - hvad der i mine øjne kun er produktivt og passende for etnografisk arbejde. Min samtale med de imperiale botanikere konkretiserer og demonstrerer denne generative etnografi om naturens ressourcer og udpeger nogle vigtige metodiske og teoretiske implikationer af en sådan form for kulturanalyse.

\section{Etnografiens natur: Et produkt af fælles forarbejdning}

Fordelagtig omgang med naturressourcer kræver en helt særlig social organisering, eventuelt over lange afstande og henover forskelle. Det var en af konklusionerne, som Howards drog i deres rapport fra 1919:

„In marketing fruit it would be an advantage if an arrangement could be made to obtain daily at Quetta the retail prices charged in Bombay and other large markets. Efficient fruit auctions at the larger centres would be an advantage to the grower.“ (A. \& G. Howard: 1919).

Den samlede ambition bag projektet Natural Goods? er at udforske naturens råvarer etnografisk ved at undersøge, hvordan fire udvalgte og vidt distribuerede råvarer - frugt og bær, kakao, te og guld - bliver konfigureret i forskellige sociale verdener, nutidigt og historisk. Dette vil vi gøre gennem et konsekvent blik for de møder og ofte meget opmærksomheds- og arbejdskrævende relationer mellem vidt forskellige parter, der får råvarerne til at træde frem, som de gør. I stedet for at se naturressourcer som stabile og givne objekter, er vores fælles grundidé altså 
at studere disse som omskiftelige og medproducerede af deres forarbejdning og videre at gøre en pointe ud af at se forarbejdning som noget, der involverer en særlig indsats for at bringe mere end en part i samspil - fx en tomat og et ark papir, eller en plukker og en temperatur, som vi så det ovenfor - og som tager form af udvinding, høst, sortering, markedsføring, international regulering, kvotering, kvalitetskontrol, prisudveksling, transportering, indpakning eller noget helt syvende.

De øvrige projektdeltageres artikler i nærværende særnummer viser dette greb gennem tætte analyser af frembringelsen af grønlandsk guld, indisk te og ghanesisk kakao. Ved at stille skarpt på disse forarbejdninger prøver vi i fællesskab at få nyt greb om, hvad naturressourcer overhovedet er og kan være, når de ses i kulturanalytisk optik. Udgangspunktet er dette: Så snart vi taler om naturen som en råvare, er den ikke længere rå, men allerede et produkt af en analyse - fx af hvordan en ressource bliver gjort økonomisk profitabel at handle med, ved at dyrkeren kender dens pris på andre markeder, eller ved at den er plukket på det rigtige tidspunkt, så dens smag bibeholdes, som det fremgik ovenfor. Det er desuden en pointe, at denne analytiske tilgang i mine øjne ikke er forbeholdt de professionelle kulturanalytikere, men derimod også kendetegner de mennesker, vi arbejder sammen med i felten - nutidigt eller via overleverede udsagn ( $\mathrm{fx}$ dem Gabrielle og Albert Howard har efterladt). Det samlende begreb om 'naturlige goder', der driver vores forskningsprojekt, er faktisk valgt for netop at udtrykke den samarbejdsrelation, som via en fælles og uafsluttelig analytisk indsats får noget til at være naturligt og genstand for en særlig interesse på én gang.

Alt dette indebærer, at den aktivitet, det er (for dyrkeren såvel som den professionelle kulturanalytiker) overhovedet at udpege en del af naturen, skære den ud af alt andet, give den en betegnelse og interagere med den, således på én og samme tid er en praktisk handling og en analytisk indgriben, der genererer et særligt objekt. Dette objekt er følgelig uadskilleligt og i lige omfang empirisk og analytisk, og i projektet er vi interesserede i at kvalificere netop de forarbejdninger, som får en kakaobønne, et teblad, et guldstøvkorn, et æble eller en tomat til at fremstå som et værdifuldt og interessant produkt for såvel forskeren som for de samtalepartnere, hun eller han møder i felten, nulevende eller fortidige.

Projektet er i det lys etnografisk i en ganske radikal forstand, fordi afsættet er, at vi anser de råvarer, vi arbejder med, for genererede i felten ud af et samarbejde mellem de aktører og figurer - mennesker, ideer, dyr, arkivalier, klassifikationer, godsvogne, kvoter, planter eller andet - som har en aktie i den, etnografen inklusive. Dette betyder, at råvarerne i udgangspunktet er underdefinerede i den forstand, at vi ser dem som under stadig tilblivelse via alle de relationer, de opstår ud af, indgår i og danner. Det afgørende her er altså en idé om, at feltarbejde er en stadig og kollektiv forarbejdningsproces, hvorigennem naturressourcer bliver skabt og hele tiden kvalificeret af en serie af laterale møder mellem forskellige 


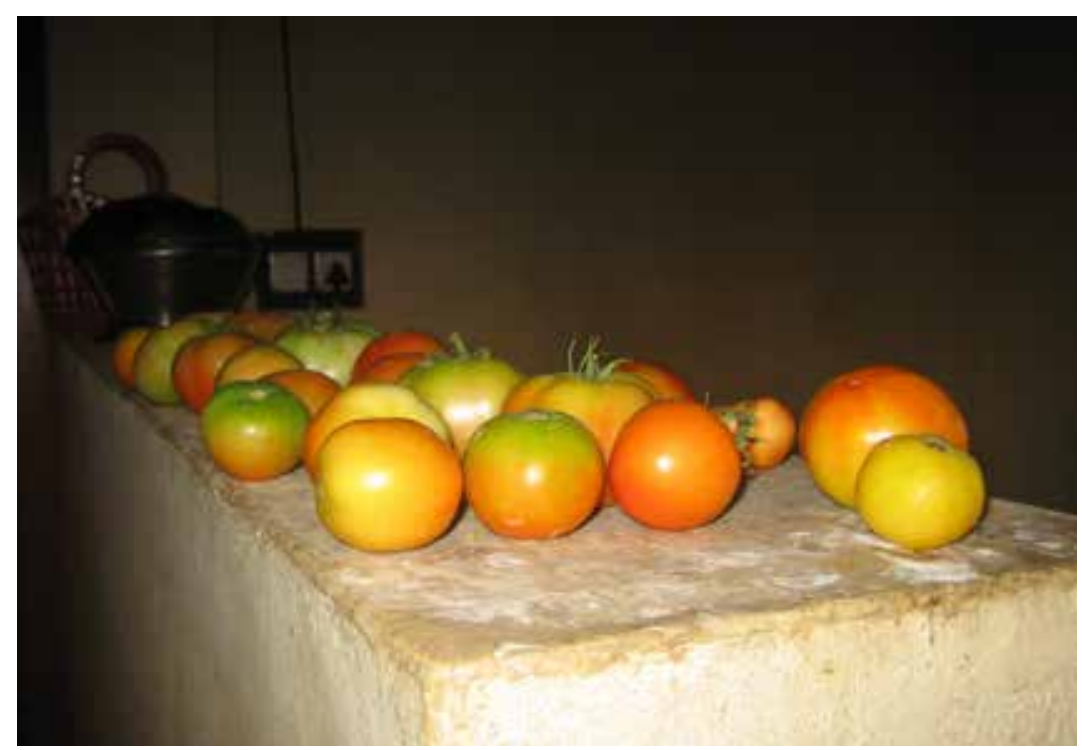

Tomater i et køkken i Tamil Nadu, Indien. Foto: Frida Hastrup

parter - mennesker som ting (jf. Hastrup 2011). Naturressourcer må i denne optik altid være sammensatte af flere end én, og vores fælles ambition er at udforske de møder og forarbejdningsindsatser, der løbende genererer råvarer som andet og mere end rå og selvidentiske. I det lys er en implikation af projektet at tematisere etnografi som gennemgribende kreativ snarere end repræsentativ; feltarbejde er under denne synsvinkel tilsvarende netop et særligt analytisk arbejde med at kombinere udsagn, observationer, erfaringer og bringe dem i en dialog eller forbindelse, der ikke er entydigt givet af den empiriske kontekst, men af en særlig vidensinteresse (se også Hastrup 2014). Af samme grund taler jeg her med Gabrielle og Albert Howard og bruger dette samarbejde til både at lære om udviklingen af den tidlige britisk-indiske frugtindustri og til at udvikle mine ideer til et generativt greb om naturressourcer, der tilsiger, at disse bliver skabt gennem kollektive og altid analytiske forarbejdningsprocesser.

Lad mig i de følgende afsnit igen vende mig mod de imperiale økonomiske botanikere, som vi mødte indledningsvist, og lade deres analyser og opmærksomhed mod detaljer indkredse og fremhæve tre gennemgående og internt forbundne temaer, hvorigennem Natural Goods? ser nærmere på forarbejdning af råvarer, nemlig henholdsvis forbindelser, kvantificeringer og værdisætninger.

\section{Forbindelser: Udbredelsen af natur}

Hvor findes globale forbindelser, hvis ikke i deres lokale, materielle virkeliggørelse? Med dette spørgsmål i baghovedet bliver denne passage om frugtkasser fra Gabrielle og Albert Howards rapport om tomater fra 1913 interessant: 
„The non-returnable crates, referred to in this paper, were made to order by the British Basket Company, Crownpoint, Glasgow, and were sent out in parts via Karachi. The boards and laths are packed flat and the punnets nested. This company is in a position to supply the materials for these crates in bulk. The complete crates are sold at Quetta for two rupees each and samples can be obtained on application to the Imperial Economic Botanist, Pusa, Bihar, at this price.“ (A. \& G. Howard 1913).

Det, vi ser her, er etableringen af en serie af forbindelser mellem kasser og bakker fabrikeret af et tjenstvilligt kurvefirma i Skotland, sendt ud i enkeltdele i transit gennem Karachi, solgt samlet i Quetta og lagret til afprøvning på en landbrugsforskningsstation i Bihar. Mens det måske ikke kan undre, at statsansatte englændere som Howards brugte britiske firmaer som leverandører af fornødenheder til brug i kolonien, eller at der var forbindelse mellem Quetta og Bihar i henholdsvis det nordvestlige og nordøstlige Britisk Indien, er det alligevel interessant at se nærmere på, hvordan nogle af disse relationer praktisk blev muliggjort, og hvordan de hænger sammen med den udbredelse og salg af naturressourcer, der var en af de økonomiske botanikeres opgaver. Et væld af detaljer og justeringer må nødvendigvis have været essentielle at få på plads, for at disse forbindelser kunne etableres og opretholdes. Fra startskuddet i 1840'erne tog konstruktionen af jernbaner på kryds og tværs af det indiske subkontinent fart i sidste halvdel af det nittende århundrede, blandt andet med det formål at lette transporten af varer mellem forskellige egne af det kæmpe areal (Wolf 1997, s. 251). Flere og flere jernbanelinjer blev føjet til Imperiet, hvilket i sig selv krævede en enorm arbejdsindsats, planlægning, utallige ingeniørberegninger ligesom også en hel del risikovillighed (Andersen 2012). Denne jætteindsats for at lægge skinner ud betød dog ikke, at forbindelser mellem forskellige dele af Britisk Indien var etableret og glattet ud en gang for alle. En hel serie af private firmaer opererede på forskellige jernbanestrækninger, hvilket ifølge Howards stod i vejen for den gnidningsløse brug af skinnerne. Dette var et problem for et eksperiment med at fragte frugt som fx ferskner fra Quetta i genanvendelige pakkasser sydpå til markederne, hvorfra de tomme kasser efterfølgende skulle sendes retur. I deres bulletin fra 1919 med titlen „Some Improvements in the Packing and Transport of Fruit in India, 3rd edition“ skriver Howards om denne udfordring og noterer sig med tydelig tilfredshed, at det for nyligt er lykkedes at uniformere disse forskellige regelsæt. Igen er et ganske langt udsagn fra Howards nødvendigt:

„The second concession recently granted refers to the return of empty fruit boxes of standard pattern from the markets to the senders. In this matter, the rules on the various railways used to be exceedingly uneven and several hampering restrictions existed. Thus on the Bombay, Baroda and Central India Railway emp- 
ty fruit packages, if carried at the quarter parcel rate, had to be returned to the station of arrival within seven days otherwise full rates were charged. In other cases, the time limit was ten days, while on the North-Western Railway and on the Oudh and Rohilkhand Railway, empty fruit boxes have been for some past years returned free on certain sections of the line. An important concession has recently been granted to the users of the returnable crates and cardboard boxes supplied by the Fruit Experiment Station, Quetta. These are now returned free to Quetta and Chaman by all the Indian Railways. This is certain to prove a material inducement to dealers to adopt better methods of packing and to invest a portion of their capital in well-made, handy crates and cardboard boxes in which their produce will travel undamaged to the most distant markets. The advantage to the railways lies in the fact that by the use of packages of standard size (which can be packed closely on the shelves of the fruit cars) the vans earn more money and the traffic is more easily and quickly handled at points where the contents have to be distributed.“ (A. \& G. Howard 1919).

I botanikernes øjne var denne standardisering af regler for fragt og for størrelsen på pakkasser gavnlig for alle og sikrede en mere rentabel afsætning af varer og en bedre udnyttelse af pladsen ombord på togene. Det, jeg her vil fremhæve, er, at denne udvidelse af forretninger i forbindelse med frugthandel - hvad enten der er tale om the British Basket Company, de lokale dyrkere i Quettas højland eller jernbanefirmaerne - ikke var en på forhånd given selvfølgelig fremskridtsproces, bygget alene på en abstrakt vilje til udbredelse og en ide om, at større er bedre. Derimod krævede frugthandlen en omhyggelig tilrettelæggelse af og løbende reaktion på en mængde små som store elementer, forventede og overraskende hændelser, der via en stor indsats skulle bringes til at passe sammen, efterhånden som arbejdet skred frem. Det er i mine øjne slående, hvor mange figurer der faktisk indgår i de ovenstående citater fra Howards skrifter, og hvilken interesse for detaljer, der må have drevet botanikerne til at entrere med skotske firmaer, at tage hyldeplads i godsvogne i øjesyn, at undersøge og aktivt prøve at ensrette regler for fragt, at tælle dagene, at designe passende pakkasser blandt meget andet.

I sit arbejde med den kostbare spisesvamp matsutake, der er en dyr delikatesse i Japan, undersøger antropologen Anna Tsing denne råvares liv og rejser for derigennem at fokusere på forestillinger om globale økonomiske strømme, ideer om forsyningskæder og praksisser for standardisering af fx naturen (se fx Tsing 2009; 2012; 2013b). Et af Tsings anliggender i dette arbejde er ud fra matsutake-svampen netop at vise, at heterogenitet og kontingens snarere end homogenisering og determinisme er konstitutive elementer i den globale kapitalismes praktiske realisering, selvom disse forsøgsvist sies ud af forestillingen om den velsmurte og selvopretholdende maskine, kapitalismen også tænkes som. Tsings pointe er kort fortalt, at det, hun anser for den globale kapitalisme så at sige altid har brug 
for noget andet end sig selv for at fungere. Forskelle, store som små, og ikke mindst samarbejde henover dem skaber således verdener af forbunden diversitet - verdener, der ifølge Tsing altid må studeres i deres specifikke fremtrædener, det vil sige lokalt, også når aktører har globale aspirationer (Tsing 2005; se også Brichet 2011). Dette grundlæggende relationelle perspektiv på (heterogent) verdensbyggeri kan man fx forfølge gennem en detaljeret og kritisk beskrivelse af svampe - undseelige men i virkeligheden allestedsnærværende organismer, der med vidtforgrenede rodnet og symbioser med andet levende, træsorter såvel som mykologer, peger på livsnødvendige forbindelser mellem stort og småt, globalt og lokalt (Tsing 2013a). Ideen om at vildtvoksende og i hvert fald delvist ukontrollable forbindelser er en uundgåelig del af det stof, som globale kapitalistiske forsyningskæder er gjort af, er interessant for de økonomiske botanikeres indsats for at udbrede en vidtrækkende handel med frugt i Britisk Indien. Selv om den imperialisme, som Howards tog del i, måske nok er sindbilledet på stort tænkt ekspansionsiver, krævede selv en sådan aktivitet en improvisatorisk indsats, hvor resultatet var foreløbigt, og praksisserne løbende måtte justeres. Markedet for den nye frugtindustri opstod ikke af sig selv som en indbringende platform for afsætning alene ud fra en forudfattet idé om en sådan, men via en omsorgsfuld bedrift for at rydde uforudsete og forudsete forhindringer af vejen. Dette arbejde bliver en del af naturressourcen og et vilkår for dens tilblivelse.

Min pointe er her, at de små handlinger, der skulle hjælpe den store ekspansion og forbedring af landbrugsproduktionen på vej - eller som i Tsings analyser hjælper global kapitalisme på vej - grundlæggende var og er sociale forhold, eksperimentelle og sammensatte af allehånde komponenter, der mødes på uforudsigelige måder. Her er vi således tilbage ved en af byggestenene i Natural Goods?, nemlig at fokusere på forarbejdning som en afgørende, ukontrollabel og fortløbende proces, der genererer værdifulde naturressourcer i felten, som altså befolkes af blandt andre botanikere, togvogne, imperiale ideer, kassefabrikanter og etnografer og konstitueres via forbindelser mellem disse.

\section{Kvantificeringer: De rette mængder}

I en tid med stadigt stigende pres på verdens ressourcer bliver det påtrængende at adressere spørgsmålet om, hvor meget natur, der er, og ikke mindst om, hvordan man egentlig opgør dette. Giver det overhovedet mening at kvantificere naturressourcer? For at tage hul på denne tematik, der ligeledes er en af de bærende i forskningsprojektet Natural Goods?, skal jeg igen vende mig mod de imperiale økonomiske botanikere, som i deres 1919-bulletin rapporterede om ændringer i måden, hvorpå forskellige jernbaneselskaber i det nordlige Indien indvejede frugt, når denne skulle transporteres, og håndterede tom emballage: 
„The rules for the transport of fruit and empty packages on the Indian railways have recently been made uniform. Two concessions have been granted. Consignments are now charged for on the collective weight and not on the weight of each separate package. Returned empties of standard pattern, recommended by the Fruit Experiment Station, Quetta, are now returned free of charge from all parts of India to Quetta.“ (A. \& G. Howard 1919).

En ændring i enheden for indvejning - hvor udgangspunktet skifter fra den enkelte pakke til en kundes samlede last - ville ifølge Howards gøre underværker for præcisionen og, skriver botanikerne et andet sted, uundgåeligt være en motivation for dyrkerne til at forsøge sig med at nå de indbringende markeder mange togstationer væk. Dette peger i mine øjne på et interessant analytisk spørgsmål om, hvilken målestok man egentlig anlægger, når råvarer bliver kvantificeret. Hvad kan et tal overhovedet? Videnskabsfilosoffen Helen Verran foreslår, at der er brug for at udvikle en sensibilitet i forhold til tal, som i hendes øjne har nogle bemærkelsesværdige egenskaber, som ikke bliver gjort tilstrækkeligt synlige, hvis man anser tal enten for universelle abstraktioner, der så at sige lægger sig uden på hele verden, eller kulturelt bestemte konstruktioner, der kun gælder inde i en lokal verden (Verran 2001; 2013). I et af sine arbejder (2013) tager Verran udgangspunkt i en artikel fra 1997 udgivet i det prestigiøse videnskabelige tidsskrift Nature, hvor forfatterne mente, at de havde regnet sig frem til den samlede numeriske værdi af alle jordens økosystemer. De tilbød med andre ord et tal opgivet i dollars, der angiveligt skulle repræsentere den totale værdi af jordens natur, som denne viser sig som ressource for mennesker og samfund. Økonomer af forskellig orientering diskuterede efterfølgende styrker og svagheder ved de kalkuler, forfatterne til artiklen i Nature havde foretaget for at nå deres resultat, ligesom nogle afviste, at man overhovedet kan sætte tal på noget, der som naturen ofte tænkes at have en iboende værdi, som netop ikke kan instrumentaliseres. Ifølge Verran er der dog plads til og brug for en helt anden slags kritik, nemlig en, der anerkender tals meddelagtighed i overhovedet at skabe virkeligheder - som samme tal så eventuelt efterfølgende kan ses som mere eller mindre præcise repræsentative kvantificeringer af. Som Verran udtrykker det: „,the workings of numbers are deeply embedded in and constitutive of the real - they lubricate its happening“ (Verran 2013, s. 112). I forhold til forskningsprojektet Natural Goods? er denne diskussion om, hvordan kvantificeringer skaber verdener og smører deres realisering interessant, fordi den peger på, at opgørelser over, hvad naturen så at sige har på lager i høj grad er et produkt af analytisk perspektiv, netop fordi det indebærer en særlig forarbejdning overhovedet at opgøre råvarer i tællelige enheder. I de imperiale botanikeres øjne var det således vigtigt, at frugtkasser i togvognene ikke blev set som enkeltstående enheder, men som en ansamling bestående af flere; her medførte opdeling i mindre enheder i Howards øjne altså fejl, mens opgørel- 
ser baseret på større klynger af varer i dette tilfælde blev set som mere eksakte. Med Verrans arbejder i tankerne er min pointe her, at tal ikke blot virker som repræsentative betegnelser med hver sin givne værdi, men i stedet som generative værktøjer, der skaber det, de tæller, på en særlig måde (Verran 2001; 2010; se også Hastrup 2012). Igen er det altså et møde, her mellem et tal og det optalte, der får verden til at træde frem på en bestemt måde, hvad der giver gode muligheder for en masse rod og for forskelle, der kun kan synliggøres og håndteres, hvis man er omhyggelig med og opmærksom på detaljer. Ligesom velanbragte jernbaneskinner ikke i sig selv sikrede en glat transport af forsyninger og emballage, som vi så det ovenfor, så kan også tal paradoksalt nok komme til kort i forhold til det, de egentlig skulle tælle, hvilket medfører, at tallene så at sige viser sig som noget andet end sig selv og påkalder sig løbende justering. Verran (2013) giver et interessant eksempel på en sådan samarbejdsproces, hvor et tal så at sige sprænger dets egne rammer, i sin analyse af tilsynekomsten og brugen af et indeks over risikoen for skovbrande i Australien, som ved at kombinere forskellige faktorer skulle kunne bestemme brandfaren på en skala fra 1-100. I 2009 skete der imidlertid det, at faren for brand ud fra de indregnede faktorer pludselig var oppe på alarmerende 186 på indekset - altså langt over skalaens egen maksimale værdi. Det interessante er her, at selvom indekset kun går til 100, så kan en kombination af de selvsamme faktorer, som indekset bygger på og beskriver, gøre, at det når ud over sin egen grænse. I denne sammenhæng er det vigtige ved et paradoks som dette, at det bliver tydeligt, at indekset ikke lægger sig uden på verden, blot fordi det er etableret med værdien 100 som den maksimale, men i stedet - ved at det har taget højde for en mængde detaljer - producerer et overskud i form af en forandret verden, hvor et brandindeks ikke længere slutter ved sin egen grænse.

Dette generative element ved kvantificeringer, der fx skaber og pakker gods i ideelt standardiserede mål, kalder på yderligere kvalificering. I Natural Goods? er det en del af opgaven at se på, hvad der viser sig, hvis tal ikke lægger sig uden på naturressourcerne, men hvis selve skalaen for tælling derimod flytter sig i takt med netop optællingen.

\section{Værdisætninger: Markedsføring af råvarer}

I en bemærkning om markedsføring af frugt fra Quetta-området skrev botanikerne Howards om den ideelle måde at sælge frugt på og om plads til forbedringer i håndteringen af de delikate varer:

„The method of offering fruit for sale is an important matter, and one in which the Indian fruit-dealers have much to learn. There should be no sorting or handling of the produce after the market is reached. The ideal method is to offer each 
unit of fruit for sale in a suitable gift package, of such a character as to encourage the purchaser.“ (A. \& G. Howard 1919).

Det, som fascinerer mig her, er de økonomiske botanikeres påpegning af, at håndtering af frugt med henblik på overskudsgivende forretning både var helt afgørende og måtte stoppe et sted. Når først de ferskner, som der her er tale om, var pakket i gaveæsker (med fire frugter i hver, som det fremgik af en illustration i botanikernes rapport), skulle sorteringen slutte og produktet forsegles som en gave af en passende størrelse, hvis det skulle appellere til købere på markederne. Der var altså forskel på, hvilken enhed frugten udgjorde henholdsvis i transit og på markederne. Man kunne sige, at den frugt, der høstedes, både var den samme og forskellig fra den, der blev solgt videre. For værdien af den fersken, der er ordenligt anbragt sammen med tre andre i en pæn gaveæske, er denne socialitet afgørende - dens relationer bliver på denne måde en del af dens kvalitet, ligesom det ville være tilfældet, hvis ferskenen blev hældt ud i en bunke på markedet sammen med andre. En strukturering af forbindelser, baseret på en særlig analyse, er på denne måde afgørende for værdisætningen. Antropologen David Graeber (2001) har, inspireret af lingvisten Ferdinand Saussure, beskrevet værdi som „,betydningsfuld forskel“. I Natural Goods? ser vi som antydet på værdisætninger af natur som uundgåeligt sammensatte og baserede på samtale, fordi parterne i enhver transaktion på den ene side skal være enige om, at en råvare har værdi for overhovedet at kere sig om den, og på den anden side skal være tilstrækkeligt uenige, for at en handel giver mening. Det vil sige, at forskel snarere end direkte ækvivalens er motoren i værdisætning, hvorved også værdi nødvendigvis bliver til gennem en social praksis - en organisering af relationer. Som antropologen Jane Guyer har bemærket, er overskud situationsbestemt, fordi handel indebærer en oversættelse mellem forskellige skalaer: „When one scale is not exactly reducible to the terms of another, a margin for gain lies in the negotiation of situational matching“ (Guyer 2004, s. 51). Ovenfor så vi, hvordan en enhed bestående af fire (ferskner) blev anset for ideel, og nu kan vi tilføje, at den situationsbestemte forhandling også indebærer, at værdisætning desuden afhænger af timing. Man kunne med Albert og Gabrielle Howard sige, at også mødet mellem tid og produkt producerer værdi:

„In connection with the work relating to the development of the fruit industry in Baluchistan, the question of the profitable production of vegetables for the Indian market was considered. Some of the English vegetables grow to perfection at Quetta and are ready for the market in July, August and September. Such produce is almost entirely absent from the markets of the Indo-Gangetic plain at this period, so that Quetta-grown vegetables would be likely to sell at remunerative 
prices, in the plains of India, if suitable methods of transport could be devised." (A. \& G. Howard 1913).

Min pointe er her, at vi ved at se nærmere på disse forskellige situationsbestemte værdisætninger kvalificerer, hvad naturressourcer overhovedet er, forstået på den måde, at deres værdi bliver en del af råvarerne selv, genereret af de møder, de i felten indgår i, snarere end noget, der tilskrives udefra. Forarbejdning er således et løbende relationelt arbejde, hvorved råvaren skifter natur. Dette skal ikke forstås som et mystisk forhold - en art trylleri, hvor en tomat ikke længere er en tomat, men det skal pege på, at der i denne tilgang til naturressourcer er en betydningsfuld forskel på, hvad en tomat er, alt efter hvilke møder den tager del i. Den rene fersken for eksempel er i en kulturanalytisk (og tilsyneladende også i en økonomisk botanisk) optik en tænkt idé, der ikke er praktisk mulig, fordi værdisætninger peger på forskelle og dermed på, at en frugt - eller et hvilket som helst andet objekt for kulturanalytisk interesse - består af mere end sig selv.

\section{På sporet af ny etnografisk teori. Om frugt blandt andet}

I det foregående har jeg talt om de grundlæggende ideer i forskningsprojektet Natural Goods? ved at fokusere på udviklingen af den imperiale frugtindustri, som Gabrielle og Albert Howard bekymrede sig om. Min inddragelse af de to botanikeres skrifter gør tydeligvis ikke min artikel til en kolonihistorie i konventionel forstand, selvom jeg måske nok kan udlede, at den engelske imperialisme ikke var en velsmurt og gnidningsløst ekspanderende maskine, men også et bumletog, hvor kreativitet og eksperimenter var nødvendige for at nå frem. Min ambition har derimod hele vejen været at pege på en vigtig kulturanalytisk pointe, der er bærende for måden, jeg udforsker naturressourcer, nemlig at man ikke kan adskille „stor“ teori (fx kolonialisme eller kapitalisme) fra „lille“ empiri (de lokale forarbejdninger, enkle frugter og små relationer, som disse teorier behandler); alt dette får udstrækning og materialiseres i et fælles sammensat og nødvendigvis offentligt eller socialt rum, der både kommer til syne i og skaber felten. Samtalen med hundrede år gamle skrifter forfattet af imperiale botanikere understreger dette vigtige element af offentlighed og generativ dialog, der også karakteriserer måden, hvorpå Natural Goods? er etnografisk.

Mit argument er her, at alle parter i de historier, hvorigennem råvarer bliver til, bedriver en form for feltarbejde, der løbende konstituerer og kvalificerer dets objekt gennem en serie af møder, hvor detaljeret forarbejdning forstået som en indsatskrævende strukturering af relationer bliver afgørende. Dette betyder, at teori kommer til syne som indlejret i små sammensatte og delte ting - ferskener såvel som frugtkasser - fordi disse bliver til som resultater af analyse, der hverken kan 
være helt privat eller så løsrevet, at relationen til felten forsvinder. Teori er i dette lys forankret i helt lokale og tilsyneladende ubetydelige møder, hvor momentan samklang opstår og giver mulighed for at tænke nye ting - om frugt og transport blandt andet og om, hvordan kulturanalyser forarbejder og dermed genererer sine objekter (se også Verran 2002). Det er i den omhyggelige berøring og omgang med frugten i felten, betinget af tilfældigheder og af, hvad der er praktisk opnåeligt og stemning for, at nye muligheder kan vise sig, snarere end i introduktion og implementering udefra af stort planlagte løsninger. Dette beskrev Howards i en passage fra deres rapport i 1919, hvor de kommenterede overvejelser om en mulig ibrugtagning af kølevogne på jernbanestrækningerne i Britisk Indien. En sådan dyr teknologisk løsning havde lange udsigter og blev mødt med skepsis, men erfaringer og eksperimenter i det små kunne alligevel få en udvikling på skinner:

„It is sometimes thought that little or nothing can be done to develop the Indian fruit trade unless the Railway Companies construct refrigerator cars and until cold-storage facilities at the large markets are provided. Experience indicates that a great field for development is open without these expensive means of transport and storage, and that the road to success lies rather in the direction of better methods of production and packing.“ (A. \& G. Howard 1919).

De nye frugtmarkeder, som Howards gerne ville bidrage til udviklingen af, kræver altså hverken mere eller mindre end erfaringsbaserede og eksperimentelle forarbejdninger foretaget i felten som et løbende og metodisk omhyggeligt arbejde med detaljer. Den form for kulturanalyse, der driver Natural Goods? videre på ruten, hviler tilsvarende på, at frugt og marked tænkes at opstå i samme bevægelse som empiri og analyse på en gang, hvorved ny teori om naturressourcer kan udvikles på tværs af tider og steder og udforskes kollektivt og etnografisk.

\section{Tak}

Jeg vil gerne takke Det Frie Forskningsråd for den generøse bevilling under Sapere Aude-programmet, som finansierer dette forskningsprojekt (se www.naturalgoods.saxo.ku.dk). Tusind tak også til Kirsten Hastrup for altid hyggelig og interessant samtale om fælles stof og til Nathalia Brichet for enestående samarbejde om projektet fra den allerførste fase.

\section{Litteratur}

Andersen, Casper 2012: „Explorer-Engineers Take the Field. Imperial Engineers, Africa, and the Late Victorian Public“. Kristian H. Nielsen, Michael Harbsmeier \& Christopher J. Ries (red.): Scientists and Scholars in the Field. 
Studies in the History of Fieldwork and Expeditions. Aarhus Universitetsforlag, s.169-190.

Brichet, Nathalia 2011: „Awkward Relations and Universal Aspirations: Common Global Heritage in Ghana“. History and Anthropology 22 (2), s. 149-168.

Gieryn, Thomas 1999: Cultural Boundaries of Science. Credibility on the Line. The University of Chicago Press.

Graeber, David 2001: Toward an Anthropological Theory of Value: The False Coin of Our Own Dreams. Palgrave Macmillan 2001.

Guyer, Jane 2004: Marginal Gains. Monetary Transactions in Atlantic Africa. Chicago University Press.

Hastrup, Frida 2011: „Shady Plantations. Theorizing Coastal Shelter in Tamil Nadu“. Anthropological Theory 2011, 11 (4), s. 425-439.

Hastrup, Frida 2012: „Certain Figures. Modelling Nature among Environmental Experts in Coastal Tamil Nadu“. Kirsten Hastrup \& Martin Skrydstrup (red.): Anticipating Nature. Routledge, s. 45-56.

Hastrup, Frida 2014: „Analogue Analysis. Ethnographic Fieldwork as Inventive Conversation“. Ethnologia Europaea 44 (2).

Howard, Albert og Gabrielle 1913: „Quetta Fruit Experiment Station, Bulletin

No 1. The Cultivation and Transport of Tomatoes in India“. Fundet på British Library, London.

Howard, Albert og Gabrielle 1919 [1915]: „Quetta Fruit Experiment Station, Bulletin No 2. Some Improvements in the Packing and Transport of Fruit in India, Third edition“. Fundet på British Library, London.

Tsing, Anna 2005: Friction. An Ethnography of Global Connection. Princeton University Press.

Tsing, Anna 2009: „Supply Chains and the Human Condition“. Rethinking Marxism 21 (2), s. 148-76.

Tsing, Anna 2012: „On Nonscalability: The Living World Is not Amenable to Precision-Nested Scales“. Common Knowledge 18 (3), s. 505-524.

Tsing, Anna 2013a: „More-than-Human Sociality: A Call for Critical Description“. Kirsten Hastrup (red.): Anthropology and Nature. Routledge, s. 27-42. Tsing, Anna 2013b: „Sorting out commodities. How capitalist value is made through gifts“. HAU: Journal of Ethnographic Theory 3 (1), s. 21-43.

Verran, Helen 2001: Science and an African Logic. The University of Chicago Press.

Verran, Helen 2002: „A Postcolonial Moment in Science Studies: Alternative Firing Regimes of Environmental Scientists and Aboriginal Landowners“. Social Studies of Science 32 (5/6), s. 729-762.

Verran, Helen 2010: „Number as Inventive Frontier in Knowing and Working Australia’s Water Resources“. Anthropological Theory 10 (1-2), s. 171-178. 
Verran, Helen 2013: „Number“. Celia Lury \& Nina Wakeford (red.): Inventive Methods. The Happening of the Social. Routledge, s. 110-125.

Wolf, Eric 1997 [1982]: Europe and the People Without History. University of California Press.

\section{English Summary}

Through a dialogue with botanists sent out from England to British India to develop the fruit trade in the early $20^{\text {th }}$ century, this article explores what natural resources might be in cultural analysis. The article introduces the central tenets of the collective research project Natural Goods? and offers a radically ethnographic take on natural resources that sees them as generated and continuously qualified in the field through encounters between different figures - be they people, fruits or other. The overall ambition of the article and of the research project as a whole is to approach natural resources as objects that come to be what they are through detailed and attentive collaborative processing, both practical and analytical in nature - a stance which has important implications for what ethnography and fieldwork might be. 